\title{
THE IMPACT OF THE DECISIONS OF THE COURT OF THE EAST AFRICAN COMMUNITY ON THE NATIONAL LEGISLATION OF THE MEMBER STATES OF THE EAST AFRICAN COMMUNITY
}

Gulnara R. Shaikhutdinova ${ }^{1}$ Anna U. Vladykina ${ }^{2}$

\begin{abstract}
The subject of this article is the jurisprudence of the Court of the East African Community in cases related to the protection of human rights. The article examines in detail the jurisprudence, which, to some degree, influenced changes in legislation in some member states of the East African Community, and in some cases prevented further violations of human rights. The authors also raise the issue of the lack of jurisdiction of the East African Court to consider complaints related to human rights violations. The authors pay particular attention to the human rights situation in Burundi, Kenya, Rwanda, and Uganda, which has developed since the Court has passed decisions. The authors also raise the issue of the place and importance of the
\end{abstract}

Court of the East African Community in the regional system of human rights protection in Africa, highlight the positive contribution of the Court to the human rights situation in the subregion. The article demonstrates the existence of complex, controversial problems, the further functioning of the court of the East African Community as a quasijudicial body for the protection of human rights depends on the need to solve it. The solution to these problems depends to a large extent on whether member states can agree to sign a protocol that gives the Court jurisdiction to handle complaints related to human rights violations in the subregion.

Keywords: African Charter on Human and Peoples' Rights; East African

\footnotetext{
${ }^{1}$ Kazan Federal University, Russian Federation, Kazan, 420008, 18 Kremlyovskaya str ${ }^{2}$ University of Management TISBI, Kazan, 420012, 13 Mushtari str Anna.arsenyuk@gmail.com
} 
Community; regional human rights system; African Court of Human and Peoples' Rights; the subregional level of human rights protection.

\section{Introduction}

$\underline{\text { States }}$ must respect human rights and fundamental freedoms for all, regardless race, gender, language, or religion. Respect for human rights is an essential factor in the peace, justice, and democracy necessary for friendly relations and cooperation between them. Particular attention is paid to the principle of respect for human rights at the regional level [1]. Speaking about the African continent, one feature should not be forgotten, namely the presence of a subregional level of protection of human rights within the courts of subregional economic communities with a mandate to protect human rights. This article will focus on the East African Community Court and the impact of its decisions on the national laws of Member States.

\section{Methods}

The research methodology is based on general scientific and private scientific methods of cognition. The following general scientific methods were applied: deduction, induction, system method, analysis, and synthesis, comparison, abstraction, analogy, modeling. Among the private scientific methods applied were technical-legal, historical-legal method, comparativelegal, formal-legal, system-structural, logical, integrated methods, and method of legal modeling.

The regulatory basis of the study is the regulatory acts of the East African Community. The empirical basis of the article was the decisions of the Court of the East African Community.

\section{Results and Discussion}

The East African Court is an international integration court aimed at resolving disputes between Member States of the East African Community. The East African Court is established in accordance with Article 9 (c) 11 of the EAC Treaty and is authorized to interpret and enforce the terms of the Treaty by Member States [3]. The court does not have the power to examine individual complaints of alleged human rights violations. However, the jurisdiction of the East African Court is secured in accordance with Art. 27 of the Treaty, which provides that "the court shall have 
jurisdiction as a court of first instance, appeal, jurisdiction for human rights and other jurisdictions, which will be determined by the Council on a suitable subsequent date" [2]. Despite the lack of clear jurisdiction of the East African Court to establish and consider cases involving human rights violations, the Court has passed judgments on individual complaints [5].

One of the most high-profile and significant was the case of Peter Anyang 'Nyong'o and others v. The Attorney General of Kenya”.

In the case of Anyana Nyongguo and others v. the Attorney General of Kenya, a statement was filed to prevent the assumption of office of nine Kenyan members who were "elected" to the East African Legislative Assembly in violation of the EAC Treaty [4].

At the core of this complaint was Article 50 of the EAC, which stipulates that the National Assembly of each Member State elects nine members of the East African Legislative Assembly (EALA) in accordance with the procedures to be determined in the State Party, and the elected members must be representatives of certain groups.
In accordance with this provision, the Kenya National Assembly adopted the 2001 Rules for the Establishment of the East African Community (election of members of the Assembly) (2001 Election Rules). The first nine EALA members from Kenya, whose term expired on November 29, 2006, were elected in accordance with these rules. The dispute arose after the election of Kenya's representatives to the Second Assembly in 2006, which led the applicants to appeal to the East African Court that the nomination and election process adopted by the Kenyan National Assembly was contrary to Article 50 of the EAC, since neither "Elections", nor any debate in parliament were held on this issue. The applicants claimed that the 2001 Election Rules did not permit the direct election of candidates for EALA by citizens or residents of Kenya or their elected representatives, and therefore were invalid because they contradicted the letter and spirit of the East African Community Treaty. In addition to the complaint, the claimants successfully filed an interim petition for judicial support prohibiting the oath of 
candidates in Kenya until a final decision on the complaint.

The defendants, on their part, argued that only the High Court of Kenya had jurisdiction to determine questions about the legality of elections held in Kenya and that the adoption by the East African Court of jurisdiction in their favor would usurp the functions of a national court.

The court in its final decision ruled that the 2001 Election Rules did not provide for a voting procedure for the selection or selection of representatives in the EALA and, therefore, did not comply with Article 50 of the EAC Treaty. Thus, Kenya violated the provisions of Article 50 of the EAC Treaty by holding "fictitious elections instead of the true elections" [4].

The immediate effect of the decision was that since Kenyan EALA candidates could not really take office, EALA could not conduct its activities because it was not fully formed as required by the EAC Treaty. Consequently, the Kenyan parliament on May 23, 2007, adopted new rules for the nomination of candidates in the form of the Treaty establishing the East African Community (Election of Assembly
Members), the 2007 Rules. According to these Rules, Parliament must discuss and approve candidates for the position of EALA members.

From the point of view of human rights, the result of compliance with the decision of the EAC court by Kenya was a legal reform in the form of developing a more representative and more democratic structure for the election of EALA members from Kenya that meets the requirements of the EAC Treaty, which, consequently, led to other rights to political participation and effective representation in the regional parliament.

However, going beyond the observance by Kenyan authorities of the adoption of new election rules, the decision had a significant impact on the Member States.

In particular, the decision of the East African Court, in this case, had an overflow effect, reflected outside of Kenya and influenced the filing of similar cases in the East African Court, contesting the EALA elections of the parties in Uganda and Tanzania, respectively. Following this decision, two cases were instituted: the Democratic Party and Mukasa Mbidde v 
Secretary-General of the East African Community [6] and the AttorneyGeneral of the Republic of Uganda and Mtikila v Attorney-General of Tanzania \& Others, and similarly led to changes in domestic law regarding the election of EALA members from these member states. Thus, the decision not only affected citizens in the other two Member States to bring similar claims to the East African Court but also contributed to legal reform in their respective jurisdictions, which helped to strengthen respect for democracy and the right to participate in political life.

Further evidence of the impact of this decision at the national level is its use as a legal precedent in litigations in national courts and, in particular, in human rights cases - an example in this regard was a reference to the decision of Anyang Nyongo by the Uganda Constitutional Court in Jacob Oulanyah v Attorney-General.

Despite a negative reaction from the EAC political organs, the chain of events that followed the decision in the Anyang Nyongo case has been an incentive for various non-state actors, including the East African Law Society, lawyers, Kenyan lawmakers, and non- governmental organizations around the East African Court to protect it from negative political consequences.

The case of Plaxeda Rugumba vs the Secretary General of the EAC and the Attorney General of the Republic of Rwanda became another important and influencing the human rights situation in Rwanda.

The applicant complained to the East African Court arguing that her brother - Sevelin Rudzhan Ngabo, a lieutenant colonel in the Armed Forces of the Republic of Rwanda, was arrested on August 20, 2010, and was detained without any contact with the outside world by the Government of Rwanda, and was formally charged.

On this basis, she applied to the East African Court stating that the arrest of her brother and detention without trial were in violation of EAC Articles 6 (d) and 7 (2).

The defendant alleged that Lieutenant Colonel Ngabo was arrested on suspicion of having committed crimes against national security and that the government had since justified his detention and held him in a well-known military prison and exercised his rights, including visits to his lawyers, family, 
and friends. This statement was filed on the basis of the decision of the Rwanda Military High Court, which on 28 January 2011 ruled that the detention of Ngabo from the date of his arrest until the charge was unlawful and contrary to the provisions of the Rwanda Code of Criminal Procedure.

Making its judgment, the EAC Court of First Instance concluded that the defendant had indeed violated the provisions of Articles 6 (d) and 7 (2) of the EAC Treaty by keeping the applicant's brother without communication with the outside world for five months [8]. The East African Court in its decision referred to the provisions of Article 6 of the African Charter, which protects against unlawful detention.

The defendant appealed against this decision on the grounds that the East African Court was not vested with human rights jurisdiction to satisfy the complaint [7]. Reaffirming its jurisdiction, the East African Court of Appeal recognized that although the East African Court did not yet have clear jurisdiction in human rights as provided for in Article 27 (2), the Court had jurisdiction to interpret and apply the provisions of the Treaty. Taking into account that the applicant relied on Articles 6 (d) and 7 (2) of the Treaty, the SAC Court cannot renounce its jurisdiction on interpretation only on the grounds that the claim includes allegations of violation of human rights. It can be argued that this case contributed to the promotion of human rights and respect for the rule of law by the Government of Rwanda, albeit indirectly. Based on the facts, Lieutenant Colonel Ngabo was arrested and detained without communication with the outside world on August 20, 2010. His older sister filed a complaint with the SAC Court on November 8, 2010. Only after this complaint was submitted to the SAC Court, at the same time in Rwanda, the national authorities referred the case to the High Military Court on January 21, 2011. The High Military Court ruled within a week and on January 28, 2011, declared that Lieutenant Colonel Ngabo's detention was unlawful and then ordered preventive detention, as provided for in the Rwanda Code of Criminal Procedure. The transfer of the case to the High Military Court was influenced by a complaint filed with the East African court, that is, the 
Government of Rwanda voluntarily tried to stop the violation of human rights. We see a unique form of influence, where filing lawsuits may prompt states to stop ongoing violations or take positive steps to fulfill their human rights obligations, thereby guaranteeing the protection of human rights in the long run.

We will further consider the case of the Burundi Journalists Union vs the Attorney General of the Republic of Burundi and then refer to it as the Media Case.

This case concerns the Law of the Republic of Burundi 1/11 "On Media" of June 4, 2013, which amended Law 1/025 of November 27, 2003, which regulates media in Burundi. The applicants claimed that the adopted media law unjustifiably restricted freedom of the press and the right to freedom of expression, which was the cornerstone of democracy, the rule of law, responsibility, transparency, and good governance. As such, these restrictions were contrary to Burundi's obligations under Articles 6 (d) and 7 (2) of the EAC Treaty. The applicant requested the Court to make a declarative statement that the Media Law violates the right to freedom of the press and the right to freedom of expression and therefore does not comply with Burundi's contractual obligations set forth in Articles 6 (d) and 7 (2) of the Treaty. In their opinion, a free press will lead to an informed electorate that can hold its leaders accountable and thus uphold the principles of good governance and democracy.

The applicants also requested to lay the Republic of Burundi under obligation to repeal the law or amend certain provisions in order to bring them into line with the EAC Treaty. The provisions of the Media Law, indicated by applicants as incompatible with the Treaty, include provisions regarding the mandatory accreditation of journalists; restrictions on material that can be published by the media; requirements to disclose confidential sources of information; regulation of print and web media; previous censorship clauses for films offered for screening in Burundi.

The Government argued that the Media Law was consistent with the EAC Treaty, and noted that the Burundi Parliament had fulfilled its legislative mandate as a representative of the people, and its decisions could not be 
replaced by the wishes of any other parties, organizations, or individuals.

In its judgment, the SAC court noted that democracy should include respect for freedom of the press and that a free press is closely linked to the principles of accountability and transparency, which are enshrined in Articles 6 (d) and 7 (2) of the EAC Treaty [10]. Accordingly, the Court declared Articles 19 (b), (g), (i) and part (j) of the Burundi Media Law as violating the principles enshrined in Articles 6 (d) and 7 (2) of the Treaty, to the extent that they unreasonably restrict the dissemination of information on currency stability; offensive articles or communications relating to public or private individuals; information that could be detrimental to state loans and the national economy; diplomacy; scientific research; and reports of the committee on state investigations. It further declared that Article 20 of the Media Law was incompatible with Articles 6 (d) and 7 (2) of the SAC Treaty to the extent that it required journalists to disclose their sources of information to the competent authorities in situations where the information concerns crimes against state security, public order, secrets of state defense and against the moral and physical integrity of one or more persons. Therefore, the Court requested the Republic of Burundi, in accordance with Article 38 (3) of the EAC Treaty, to immediately take measures to implement the decision within its domestic legal mechanisms.

The direct impact of this decision was that the Parliament of Burundi revised the Media Act and proposed new amendments to it that would eliminate the controversial provisions in accordance with the decision of the East African Court [5]. These amendments were discussed and approved by the Senate. The new media law 1/15 was adopted on May 9, 2015. At the same time, a number of laws were passed that were considered repressive in order to restrict freedom of assembly and freedom of information, and, in particular, with reference to the regulation of the use of social networks and the Internet. Thus, on the one hand, there was compliance with the decision of the EAC court, however, the general human rights situation in Burundi changed for the worse after the decision was made [6]. In this case, the decision did not have a great positive effect. 


\section{Summary}

A review of several cases analyzed in the article shows that going beyond the observance of the judgments of the Court by the respective member states, one can trace the influence of the decisions of the East African Court on the discourse on human rights in the EAC member states at different levels [6]. The analysis showed that the decisions of the EAC court had an impact on the national judicial authorities in the Member States in determining disputes at the national level. Although this argument has only been documented in relation to Uganda, the references to the Anyang Nyongo case by the Ugandan Constitutional Court demonstrate the potential of the SAC court's decisions affecting the development and interpretation of national laws.

The second level of influence is found in the "wave effect" when specific decisions of the SAC court inspired supporters and non-state actors in other member states to make substantiated complaints about human rights violations in the SAC court. For example, the Anyang Nyongo case promoted the filing of similar cases in
188

the EAC court from Uganda and Tanzania in connection with the election of representatives of these member states to the EALA.

Thirdly, although in most cases the decisions of the EAC court had a positive impact on the human rights system, the political reaction caused by its interim decision in the Anyang Nyongo case had a negative impact both in the short and long term [6]. The consequences of amendments to the SAC Treaty, and in particular with regard to the 60-day deadline for filing a complaint, deprive plaintiffs of access to justice even in cases where grave human rights violations are alleged. However, Anyang Nyongo's case has prompted activists and NGOs to create a large network that has been involved in lengthy litigation in the SAC court in the areas of governance and human rights. The decisions of the EAC court have served to deter certain violations by the Member States. Respect for human rights standards and the influence considered in this context can be expressed in refraining from actions that amount to violation of human rights in the context of the EAC Treaty. 
This conclusion is closely related to a special type of influence, based not on the decision of the SAC Court itself but on the fact of filing a complaint with the Court. This was clearly evident in the Rugumba case, when the Rwandan authorities hastened to prevent the violation, having learned that a complaint had been filed with the EAC court.

\section{Conclusion}

Hence, the decisions of the East African Court had both direct and indirect influence on state and non-state actors, which led to increased protection of human rights. It is important to note that the East African Court lacks a statutory mandate to deal with complaints of human rights violations. Considering that there is no mandatory contractual obligation of member states to give the EAC Court jurisdiction in human rights, we can argue that the EAC Court will have a greater impact on national human rights practice if it can make decisions binding on the member states of the Community in the field of human rights, as provided for in its memorandum of association. In addition, the integration of the East African
Community into a regional human rights system requires an appropriate and reliable structure for the promotion and protection of human rights, which includes an EAC Court with clear jurisdiction to deal with complaints of human rights violations.

\section{Acknowledgments}

The work is performed according to the Russian Government Program of Competitive Growth of Kazan Federal University.

\section{References}

International law. Kurdyukov G.I., Abdullin A.I., Biryukov P.N., Davletgildeev R.Sh., Valeev R.M., Kayumova A.R., Marochkin S.Yu., dr. Bachelor textbook / Moscow, 2017

Vladykina A.U. Some aspects of the protection of human rights within the East African Court. Materials of the Annual Scientific and Practical Conference with International Participation (Kazan, December 7, 2018,/ Edited by NM Pruss, AA Ayupov. - Kazan: University “TISBI”, 2018. 
Mezyaev A.B. International Courts and Africa // Asia and Africa today. 2005. №11;

Gulnara Shaikhutdinova, Anna Arseniuk. Some aspects of the protection of human rights in the East African Court/ Herald NAMSCA. -2018.-№ 3 (2) - p.102-104. ISSN: 2226-3209;

Solncev A.M., Bazadze B.M. Subregional'nye mekhanizmy zashchity prav cheloveka $\mathrm{V}$ Afrike// Afrika V poiskah istochnikov mira i razvitiya: Ezhegodnik-2013: Sb. statej/ Pod red. N.S. Kirabaeva, L.V. Ponomarenko, V.I. YUrtaeva, E.A. Dolginova. - M: RUDN, 2013.

V. Lando The domestic impact of the decisions of the East African Court of Justice. African Human Rights Law Journal .2018(18).p. 463-485;

«Peter Anyang' Nyong'o \& 10 Others v the Attorney-General of the Republic of Kenya \& 5 Others EACJ» Reference 1 of 2006 and EACJ Appeal 1 of 2009: http://eacj.org/wpcontent/uploads/2012/11/Appeal-no-1of-2009.pdf
«Democratic Party and Mukasa Mbidde $\mathrm{v}$ The Secretary-General of the East African Community and the AttorneyGeneral of the Republic of Uganda EACJ» Reference 6 of 2011, First Instance Division; and Mtikila v Attorney-General of Tanzania \& Others EACJ Reference 1 of 2007.

«East African Law Society Vs The Attorney General of the Republic of Burundi and the Secretary General of the East African Community» Reference NO.3 of 2014: http://eacj.org/wpcontent/uploads/2014/08/APPLICATIO N-NO-03-OF-2014-THE-EASTAFRICAN-LAW-SOCIETY-AGBURUNDI-15-AUGUST-20141.pdf

«Burundi Journalists Union Vs The Attorney General of the Republic of Burundi» Reference NO.7 of 2013: http://eacj.org/wpcontent/uploads/2015/05/ReferenceNo.7-of-2013-Final-15th-May-2c-2015Very-Final.pdf 